
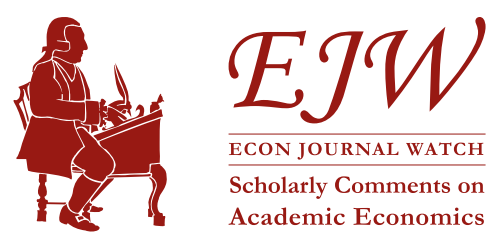

ECON JOURNAL WATCH 11(2)

May 2014: 170-178

\title{
Entrepreneurship and Islam: An Overview
}

\author{
M. Kabir Hassan ${ }^{1}$ and William J. Hippler, III $^{2}$
}

\section{LINK TO ABSTRACT}

In this article, we provide an overview of entrepreneurship from an Islamic perspective. We compare and contrast the Islamic perspective with the Western perspective. The discussion includes a brief review of the incentives, types of entrepreneurial activities, and financing arrangements typically employed by Islamic entrepreneurs. The influence of Islamic laws plays a significant role in shaping Islamic entrepreneurial activity. Additionally, the incorporation of Islamic laws makes it inappropriate to compare the relative success of the Western and Islamic entrepreneurial frameworks by using size, total productivity, the amount of wealth generated, or similar financial measures. Islamic laws impose altruistic goals on entrepreneurs that make such measures unsuitable.

Islam stresses the importance of engaging in economic activities that advance the goals of society as a whole, and many of the limitations placed on Muslim entrepreneurs are meant to reduce activities that can harm society. Some activities that are prohibited by Shariah are deemed harmful from a moral standpoint, such as those involving alcohol and gambling. Others, however, acknowledge the need to maintain a stable and just economy. Such limitations include the prohibition of taking unnecessary risks and speculation. The recent financial crisis exposed many of the risks associated with the relatively unrestricted economic activities of Western economies. A comparison between and understanding of different economic perspectives and their respective outcomes is particularly relevant as global economies evolve to strike the appropriate balance between open economies that provide the freedom of entrepreneurs to maximize

1. University of New Orleans, New Orleans, LA 70148.

2. University of La Verne, La Verne, CA 91750. 
their utility with the constructs needed to ensure the well-being and stability of society.

\section{The Islamic view of entrepreneurship}

A casual glance at the state of world economies and economic progress can undoubtedly lead one to conclude that the economic systems of finance and entrepreneurship that have been established by Western economies, namely in Europe and the United States, have far surpassed those of Islamic economies. Indeed, advocates of Western economies often point to the Western entrepreneur as the cornerstone of its success in modern times. Advocates of Western economies sometimes point to the relative financial success of Western business activities as evidence of the superiority of Western practices over those of Islamic systems. Such advocates often assert that religion-based economies hinder economic growth, or that they don't provide adequate incentives or motivation to engage in productive business ventures. The discrepancy between Islamic and Western economies, however, is due mostly to philosophical differences between Islamic and Western economic practices and the benchmarks with which they are measured.

The charge that the Islamic religion does not motivate entrepreneurial behavior is erroneous. In fact, engaging in productive or entrepreneurial endeavors is encouraged and even demanded in the teachings of Islam (Kayed and Hassan 2011; Adas 2006). Islam places a great deal of focus on prayer, but equal importance is placed on earning a living in order to support oneself, one's family, and society. Every Muslim is charged with making a living according to the tenets of the Qur'an and Shariah laws, the set of Islamic teachings. One such way of earning a productive living is through engaging in economic activities that provide for the real economic needs of society. Thus, by engaging in entrepreneurial activities, Muslims can fulfill their religious obligation to please Allah.

There are, however, some philosophical differences between Islamic and Western perspectives with regards to how entrepreneurship is viewed and measured. In the traditional, Western view of entrepreneurship, the raison d'etre of economic activity is typically thought of as the individual utility maximization of the economic agents involved, and success is often measured by the financial gains reaped from business endeavors. In this framework, even though the entrepreneur may indirectly benefit others and society through his or her economic activities, societal welfare is not typically a primary motivation for engaging in new business ventures. In addition, even though Western entrepreneurs must adhere to ethical and legal constraints, there is no inherent religious aspect to the entrepreneurial 
process. In general, the success of a Western entrepreneur is often defined by the ability of the entrepreneur to maximize his or her personal financial benefits, and any additional benefits that aid in societal or religious goals are secondary.

The Islamic perspective of entrepreneurship has one major difference. Unlike Western entrepreneurs, who are free to separate business and religious practices if they wish, Islamic practices dictate that all transactions, including those of entrepreneurs, should strive to meet religious goals. In the context of Islam, a Muslim's business activities must be focused foremost on pleasing Allah, which includes conducting a business consistent with the moral and ethical standards of Islamic practices, fulfilling one's religious obligations, and contributing to the overall Islamic goal of benefitting society as a whole. From this perspective, in a truly Islamic entrepreneurial framework, religion and economic activities are inseparable, and, as a result, the set of economic behaviors are guided not simply by secular, legal, and ethical guidelines, but by religious guidelines as well.

Additionally, because fulfilling religious obligation is a major motivation for Muslim entrepreneurs, the measures used to evaluate their success are also different. The Western entrepreneur typically judges successes by the financial gains reaped by the business venture. However, the religious aspect of Islamic entrepreneurship implies that success is measured not only by personal financial success, but also by how well religious goals are achieved, which may provide the entrepreneur with rewards in the afterlife. This view is consistent with the Western idea that Islamic entrepreneurs maximize their utility; however, that utility is also derived through religious fulfillment that may not be directly related to financial wealth (Campante and Yanagizawa-Drott 2013).

\section{Islamic laws and entrepreneurial activity}

The lack of separation between religious and business ventures in an Islamic economic framework has significant implications with regards to the activities in which Muslim entrepreneurs are able and willing to engage. ${ }^{3}$ In Western economies, business activities are limited by (1) the ethical standards imposed by laws and regulations, (2) the contractual relationships entered into by the entrepreneurs, and (3) the personal standards and goals of those involved. The personal standards of the agents involved may include religious or other personal beliefs that encompass a wider range of activities than those that are otherwise imposed; however, this

3. Kayed and Hassan (2011), Vargas-Hernández, Noruai, and Sariolghalam (2010), and Akbar (1993), among others, provide discussions of the incentives and types of entrepreneurial activities from an Islamic perspective. 
is not necessarily the case. In contrast, Islamic entrepreneurs have the additional responsibility to ensure that business ventures are in adherence with Islamic beliefs as presented in the Qur'an and Shari'ablaw, the set of Islamic doctrines.

Muslim entrepreneurs must engage in business ventures with a pre-designed desire to engage in an activity that pleases Allah. Consequently, ventures that involve activities that are forbidden under Shari'ab law are not pursued by Muslim entrepreneurs. While some economic activities, like those involving illegal drugs and prostitution are also prohibited by Western laws, others, such as those dealing with alcohol, gambling, usury, speculation, etc., are often undertaken by Western entrepreneurs, but are strictly prohibited by Shariah law, and, thus, cannot be pursued by Islamic entrepreneurs.

Another key distinction between Islamic and western entrepreneurship practices stems from ideological differences with regards to the use of money and the ideal distribution of wealth. In Islamic economies, money serves a slightly different function than that in Western economies. In Islam, economic transactions are only valuable and permitted if they involve or facilitate the transfer of real goods and services that satisfy the needs of society. Money is valuable as a medium of facilitating legitimate economic transactions, but the trade of money itself is not considered a permissible economic end. Transactions that involve the trading of money as a commodity or the trading of monetary goods without a connection to an underlying real asset is prohibited by Shariah and, thus, not pursued by Islamic entrepreneurs. Additionally, Shari'ab laws and Islamic practices prohibit Muslims from engaging in practices that involve excessive amounts of risk, uncertainty, and speculation. As a result, the religious beliefs of Muslim entrepreneurs guide them to reject economic activities that involve excessive amounts of uncertainty and avoid trading in assets of an overly risky nature, such as speculation on commodities or other forms of derivatives.

Finally, the Islamic perspective on the permissible uses of money in economic transactions leads to the prohibition of usury or interest in Islamic economies. The Islamic economy is often referred to as an "interest-free economy," and this is a key difference between western and Islamic economic systems. The prohibition of interest in Islam is founded on several basic laws. First, the payment of interest involves the exchange of money for money, which is inconsistent with the Islamic view that money itself should have no direct value. Secondly, the charging or payment of interest is inconsistent with the ideals of economic fairness and the desire for equality of economic opportunity presented in Islamic teaching. The payment of interest tends to favor the minority who are already wealthy, and multiplying their wealth through interest payments does not serve a valuable societal function and only increases the disparity between the rich and poor. Additionally, demanding fixed interest payments from the poor in 
exchange for capital can lead to a cycle of debt that can make it difficult for them to improve their economic situation. From the prohibition of usury in the interestfree economy, Islamic entrepreneurs avoid enterprises that engage in the practice of usury.

\section{Financing Islamic business ventures}

Although the incentives for entrepreneurial ventures are similar across Western and Islamic economies, there are some key differences with regard to the philosophical underpinnings of each system. Another key difference between Islamic and Western entrepreneurial models lies in the financing of business ventures. ${ }^{4}$ In Western economies, entrepreneurs face two main financial mechanisms for realizing their economic opportunities: debt and equity. In particular, for smaller-scale projects, where the entrepreneur does not have the connections necessary to gain equity financing, debt agreements in the form of small business loans are commonly employed. In Islamic economies, however, the prohibition of interest precludes the use of this popular Western method of finance. As a result, Islamic economies have had to develop alternative means of entrepreneurial financing.

Even though debt financing involves the lending of money in order to facilitate the acquisition of real capital for useful economic production, debt financing arrangements are precluded from Islamic economies because they are considered unethical and unfair. Under a debt arrangement, when the venture does extremely well, the lender still only receives the fixed interest payment. Thus, lenders are only motivated to finance projects of lower risk in order to ensure their repayment. As a result, higher-risk, and often the most innovative ventures, may go unfunded. On the other hand, if the venture goes poorly, the entrepreneur is still obligated to pay the fixed debt payment. Thus, the entrepreneur is often motivated to engage in riskier projects in order to maximize his profits and ensure debt repayment. This conflict of interest between lenders and entrepreneurs under fixed debt payments has been documented and often results in an overall increase in the costs of financing. ${ }^{5}$ Consequently, this arrangement is one that is held by Islamic teachings as inherently unfair.

4. See Ahmad (2000) and Kayed and Hassan (2011; 2014; N.d.) for more detailed discussion of the Islamic financial system and mechanisms for funding Muslim entrepreneurs.

5. Jensen and Meckling (1976), Garven and Pottier (1995), and others discuss agency problems caused by fixed-interest debt contracts. Garven and Pottier (1995) assert that agency issues can cause higher costs of capital. 
As an alternative to debt financing, Islamic economies have developed arrangements that aim to provide capital to Muslim entrepreneurs in a more equitable fashion, as well as to align the incentives between the entrepreneur and the lender. Two such arrangements, mudarabah and musharakah, are essentially profit sharing agreements. Under these agreements, the entrepreneur is able to borrow money from a financial institution, but instead of interest payments the financial institution receives a predetermined share of the profits (or losses). Under a mudarabah relationship, the financial institution typically supplies all the capital needed, and the entrepreneur is charged with providing his or her expertise in carrying out the venture. Musharakah is a similar relationship; however, under this arrangement, the entrepreneur typically supplies some capital as well. Musharakah tends to be the financing mechanism preferred by most financial institutions, because it most aligns the interests of the lender and the entrepreneur.

\section{Entrepreneurial activities across economies}

The starkest difference between Western and Islamic entrepreneurship is the inseparability of religious laws and motivations from the business activities of Muslim entrepreneurs. Islamic laws set forth from the Qu'ran and Shari'ablaw play a major role in shaping the types of Islamic entrepreneurial ventures, the manner in which they are conducted, and the mechanisms in which they are financed. In essence, the realm of Islamic entrepreneurial behavior is a subset of the potential Western entrepreneurial activities, because some entrepreneurial activities and financial mechanisms are not pursued by Muslims due to religious values. Figure 1 depicts the set of entrepreneurial activities and shows that Islamic activities are a subset of those possible under Western economic systems. Some key characteristics that differentiate the two systems are also highlighted.

Critics of Islamic or religion-based economic systems will interpret Figure 1 as evidence that incorporating Islamic beliefs into entrepreneurship is restrictive and leads, consequently, to a less successful system; however, this is not necessarily the case. Muslim entrepreneurs do not judge the success of the Islamic economy simply by the amount of productivity or wealth generated, but also by how well the economy conforms to their religious laws. Proponents of Islamic economies argue that the prohibition of certain endeavors or business practices is acceptable and may even be beneficial, because these practices, such as charging interest, do not contribute (or are harmful) to society. This claim is supported by the recent experience of how complicated derivative transactions, which are precluded in Islamic economies, contributed to the financial crisis of 2008-2009. Islamic teaching also defines successful economic activity to be that which helps create a more 
balanced society, and hoarding wealth is prohibited. Some Western economies, on the other hand, have a significant degree of wealth inequality. Assessing the relative success of the Islamic entrepreneurial system is thus difficult, because there are different measures of entrepreneurial success.

Figure 1. Entrepreneurial activities

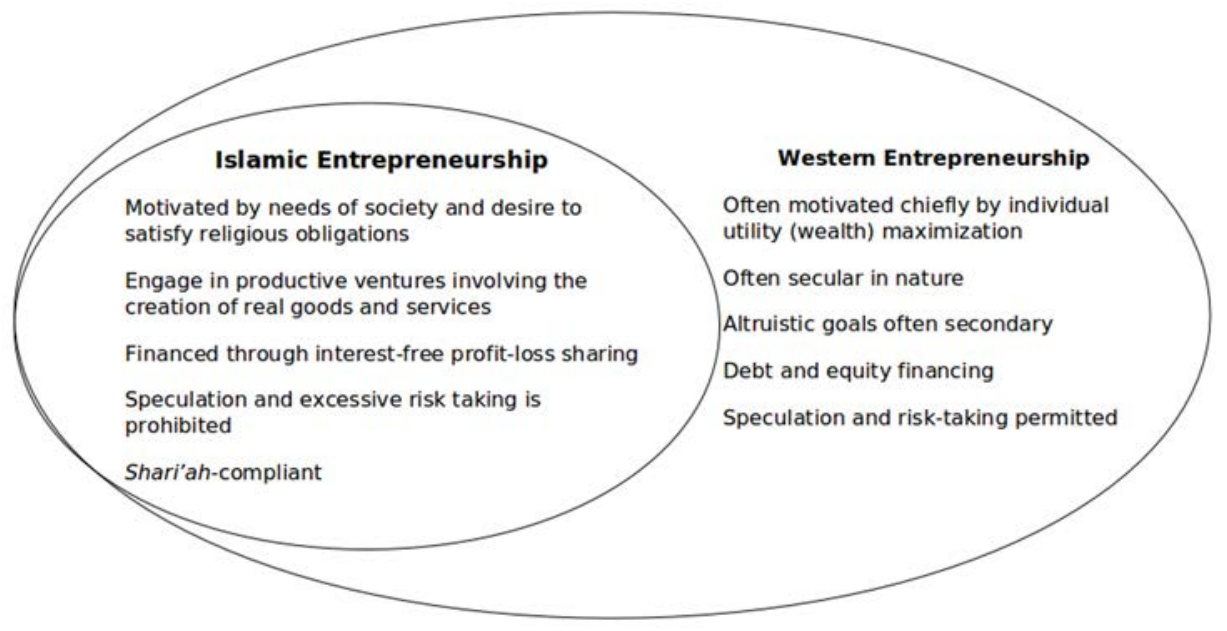

\section{Conclusion}

Both Western and Islamic economies provide significant incentives for engaging in entrepreneurial activities. However, there are key differences between the two systems that may drive the differences in their respective entrepreneurial output. Although Western entrepreneurs often have profit maximization as a chief goal, Muslim entrepreneurs have an obligation to also pursue religious and societal needs. Muslim entrepreneurs comply with the laws of Shari'ablaw, which precludes them from engaging in ventures dealing with alcohol, drugs, gambling, usury, speculation, etc. Additionally, the non-interest Islamic economy has developed profit-sharing mechanisms like mudarabah and musharakah as a means for financing potential endeavors without the need for Western fixed-interest loan arrangements. Due to the inseparability of religion and business activities inherent in the Islamic entrepreneurial model, it is inappropriate to judge the relative success of Islamic entrepreneurial activity by the same metrics as the Western system (total productivity, wealth generated, etc.), because Muslim entrepreneurs have altruistic and religious goals that inform their idea of successful business enterprise. 


\section{References}

Adas, Emin Baki. 2006. The Making of Entrepreneurial Islam and the Islamic Spirit of Capitalism. Journal for Cultural Research 10(2): 113-137.

Ahmad, Khurshid. 2000. Islamic Finance and Banking: The Challenge and Prospects. Review of Islamic Economics 9: 57-82.

Akbar, M. 1993. Ideology, Environment and Entrepreneurship: Typologies from Islamic Texts and History. Journal of Entrepreneurship 2(2): 135-154

Campante, Filipe, and David Yanagizawa-Drott. 2013. Does Religion Affect Economic Growth and Happiness? Evidence from Ramadan. Working paper. Link

Garven, James R., and Steven W. Pottier. 1995. Incentive Contracting and the Role of Participation Rights in Stock Insurers. Journal of Risk and Insurance 62(2): 253-270.

Jensen, Michael C., and William H. Meckling. 1976. Theory of the Firm: Managerial Behavior, Agency Costs and Ownership Structure. Journal of Financial Economics 3(4): 305-360.

Kayed, Rasem N., and M. Kabir Hassan. 2011. Islamic Entrepreneurship. New York: Routledge.

Kayed, Rasem N., and M. Kabir Hassan. 2014. Finance, Entrepreneurship, and Economic Development in Islam. In Islamic Finance and Development, eds. S. Nazim Ali, Umar Oseni, and Shariq Nisar, 69-88. Cambridge, Mass.: Harvard Law School.

Kayed, Rasem N., and M. Kabir Hassan. N.d. An Islamic Perspective of Entrepreneurship. Working paper.

Vargas-Hernández, José G., Mohammad Reza Noruzi, and Narges Sariolghalam. 2010. An Exploration of the Affects of Islamic Culture on Entrepreneurial Behaviors in Muslim Countries. Asian Social Science 6(5): 120-127. Link 


\section{About the Authors}

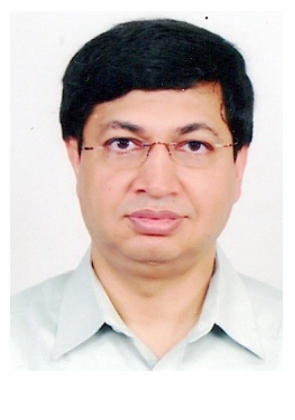

M. Kabir Hassan is Professor of Finance and Hibernia Professor of Economics and Finance in the Department of Economics and Finance at the University of New Orleans. He is co-author (with Rasem Kayed) of Islamic Entrepreneurship (Routledge, 2011) and co-author (with Dr. Kayed and Umar A. Oseni) of the textbook Introduction to Islamic Banking \& Finance: Laws and Practice (Pearson, 2013). His email address is mhassan@uno.edu.

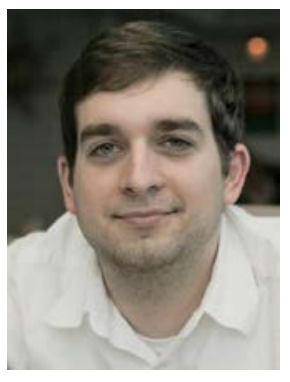

William Hippler is a recent graduate of the University of New Orleans. In the fall of 2014, he will be joining the faculty of the University of La Verne as Assistant Professor of Finance. His email address is wjhipple@uno.edu.

Go to Archive of Economics in Practice section Go to May 2014 issue 